\title{
Human papillomavirus (HPV) coinfection with other sexually transmitted infections in patients of the Department of Dermatology and Venereology at the Medical University of Warsaw
}

\author{
Zakażenie wirusem brodawczaka ludzkiego (HPV) wspótistniejące z innymi \\ zakażeniami przenoszonymi drogą płciową u pacjentek Kliniki Dermatologii \\ i Wenerologii Warszawskiego Uniwersytetu Medycznego
}

Ewa Bukowska', Beata Młynarczyk-Bonikowska', Magdalena Malejczyk', Grażyna Przedpełska', Szymon Walter de Walthoffen², Grażyna Młynarczyk², Sławomir Majewski³

'Department of Diagnostics of Sexually Transmitted Diseases, Medical University of Warsaw, Warsaw, Poland 2Department of Medical Microbiology, Medical University of Warsaw, Warsaw, Poland

${ }^{3}$ Department of Dermatology and Venereology, Medical University of Warsaw, Warsaw, Poland

'Zakład Diagnostyki Chorób Przenoszonych Drogą Płciową, Warszawski Uniwersytet Medyczny, Warszawa, Polska ${ }^{2}$ Katedra i Zakład Mikrobiologii Lekarskiej, Warszawski Uniwersytet Medyczny, Warszawa, Polska

${ }^{3}$ Klinika Dermatologii i Wenerologii, Warszawski Uniwersytet Medyczny, Warszawa, Polska

\section{CORRESPONDING AUTHOR/} ADRES DO KORESPONDENCJI: dr hab. Beata Młynarczyk-Bonikowska

Zakład Diagnostyki

Chorób Przenoszonych

Drogą Płciową

Warszawski Uniwersytet

Medyczny

ul. Koszykowa 82 A

02-008 Warszawa, Polska

tel.: +48225021313

e-mail: beata.mlynarczyk@wum. edu.pl

\begin{abstract}
Introduction. Infections with the genital types of human papillomavirus (HPV) are usually eliminated by the immune system within 6-18 months. Other concurrent sexually transmitted infections may be one of the factors contributing to the infection and its longer persistence.

Objective. To assess the prevalence of HPV and coinfections with other sexually transmitted infections.
\end{abstract}

Material and methods. Forty women with at least one sexually transmitted infection and 45 women from the control group were examined. For gonorrhea and chlamydial infection diagnostics, culture and direct immunofluorescence were applied, respectively. In parallel, both infections were diagnosed using real-time PCR. Syphilis was diagnosed using serological tests VDRL and FTA-ABS tests, and HIV infection with enzymatic immunoassay. Real-time PCR was used to detect HPV6, 11, 16 and 18.

Results. HPV infection was found in $60 \%$ of women in the study group and $42.22 \%$ in the control group. HPV16 infection was diagnosed in $58.3 \%$ of women infected with $C$. trachomatis, $57.9 \%$ with gonorrhea, $16.7 \%$ with syphilis and $26.7 \%$ of women in the control group. The percentage of those infected with two types of HPV in the study group was $22.5 \%$, and $13.33 \%$ in the control group. A relationship was found between HPV16 infection and gonorrhea and chlamydial infection and between gonorrhea and infection with two different types of HPV.

Conclusions. The obtained results indicate the influence of C. trachomatis and N. gonorrhoeae infections on the persistence of oncogenic HPV infections, which may lead to an increased risk of developing pre-cancerous lesions. 


\section{STRESZCZENIE}

Wprowadzenie. Zakażenia genitalnymi typami wirusa brodawczaka ludzkiego (HPV) są przeważnie eliminowane przez układ odpornościowy w czasie 6-18 miesięcy. Jednym z czynników sprzyjających zakażeniu i jego dłuższemu utrzymywaniu się może być współistnienie innych zakażeń przenoszonych drogą płciową.

Cel pracy. Ocena częstości występowania HPV oraz współistnienia zakażenia HPV i innych zakażeń przenoszonych drogą płciową.

Materiał i metody. Przebadano 40 kobiet z co najmniej jedną chorobą przenoszoną drogą płciową oraz 45 kobiet $\mathrm{z}$ grupy kontrolnej. $\mathrm{W}$ diagnostyce rzeżączki i chlamydiozy wykorzystano odpowiednio hodowlę i immunofluorescencję bezpośrednią. Jednocześnie przeprowadzono diagnostykę obu zakażeń metodą real-time PCR. Kiłę diagnozowano testami serologicznymi VDRL i FTA-ABS, a zakażenie HIV testem immunoenzymatycznym. Do wykrywania HPV 6, 11, 16 i 18 zastosowano metodę real-time PCR.

Wyniki. Zakażenie HPV stwierdzono u 60\% kobiet z grupy badanej i u 42,22\% z grupy kontrolnej. Zakażenie HPV 16 dotyczyło 58,3\% kobiet zakażonych Chlamydia trachomatis, 57,9\% kobiet z rzeżączką i 16,7\% z kiłą oraz 26,7\% kobiet z grupy kontrolnej. Odsetek kobiet zakażonych dwoma typami HPV w grupie badanej wynosił 22,5\%, a w grupie kontrolnej 13,33\%. Stwierdzono zależność pomiędzy zakażeniem HPV 16 a rzeżączką i chlamydiozą. Występowała również zależność między rzeżączką a zakażeniem dwoma różnymi typami HPV.

Wnioski. Uzyskane wyniki potwierdzają możliwość wpływu zakażeń C. trachomatis i Neisseria gonorrhoeae na utrzymywanie się zakażenia onkogennymi HPV, co może powodować zwiększone ryzyko rozwoju zmian przednowotworowych.

Key words: human papillomavirus, Neisseria gonorrhoeae, Chlamydia trachomatis, comorbidity.

Słowa kluczowe: wirus brodawczaka ludzkiego, Neisseria gonorrhoeae, Chlamydia trachomatis, współistnienie.

\section{INTRODUCTION}

Human papillomaviruses (HPV) belong to the family Papillomaviridae and genus Papillomavirus. In the International Human Papillomavirus Reference Center, 226 types of this virus have been sequenced and assigned a name [1]. HPV is a non-enveloped virus, formed of a capsid (built up of 72 capsomers) containing a single, circular double-stranded DNA molecule. Although HPV are a heterogeneous group, they have similar structure and organization of the genome $[2,3]$. On the basis of several hundred base pair sequence analysis in the L1 region, HPV DNA was divided into five groups $(\alpha, \beta \gamma, \mu, v)$ with different affinity to the epithelium and pathogenic potential [4]. The largest group is group $\alpha$, containing HPV types of high oncogenic risk, associated with, among others, cervical cancer as well as low risk, causing mild hyperplastic lesions of the mucous membranes

\section{WPROWADZENIE}

Wirusy brodawczaka ludzkiego (human papilloma virus - HPV) należą do rodziny Papillomaviridae i rodzaju Papillomavirus. W Międzynarodowym Ośrodku Referencyjnym Wirusa Brodawczaka Ludzkiego (International Human Papillomavirus Reference Center) zsekwencjonowano i nazwano łącznie 226 typów tego wirusa [1]. HPV jest wirusem pozbawionym otoczki, składającym się z kapsydu (zbudowanego z 72 kapsomerów) zawierającego pojedynczą cząsteczkę dwuniciowego kolistego DNA. Wirusy HPV stanowią niejednorodną grupę, odznaczają się podobną budową i organizacją genomu $[2,3]$. Na podstawie analizy sekwencji kilkuset par zasad w regionie L1 DNA wirusy HPV podzielono na pięć grup $(\alpha, \beta, \gamma, \mu, v)$ różniących się powinowactwem do nabłonka i potencjałem chorobotwórczym [4]. Największa jest grupa $\alpha$ obejmująca typy HPV o wysokim ryzyku onko- 
and skin [2]. It is estimated that about $60 \mathrm{HPV}$ types from group $\alpha$ infect the cervical epithelium, and 30 of them are associated with the pathogenesis of cervical cancer. HPV 16 is the most frequently detected highrisk virus, responsible for $50-60 \%$ of cervical cancers, while HPV 18 causes about $10 \%$ of these cancers [4].

Infections with genital HPV types occur mainly by sexual contacts, less often through another route, such as transfer of the virus from the mother to the child during pregnancy or childbirth, or during taking care of the child. Most sexually active women are infected at least once with HPV during their life [5] These infections remain mainly asymptomatic and are eliminated by immune cells within 6-18 months [6]. Only in a small percentage of women does HPV infection persist, which in the case of high-risk HPV may contribute to the development of high-grade cervical intraepithelial neoplasia (CIN), which may progress to cervical cancer $[5,7,8]$. The region of the cervical epithelium at the site of the transformation zone (transition from the stratified squamous epithelium into the columnar epithelium) is the most susceptible to high-risk HPV infection [9]. It is estimated that approximately 290 million people are infected with HPV every year in the world. In 2018, these viruses caused 570,000 new cases of cervical cancer and 311,000 deaths due to this cancer [10]. According to the World Health Organization (WHO), $85 \%$ of these deaths occur in developing countries. However, HPV infection is a global problem. CDC (Centers for Disease Control and Prevention) data show that in the United States, approximately 14 million people are infected with HPV every year, 12,000 women a year suffer from cervical cancer and 4,000 die of it. Poland is among the countries with the highest incidence rates in Europe (over 3,000 cases per year) and cervical cancer mortality ( 7.9 cases per 100,000 women) [11].

It is believed that the persistence of HPV infection and the development of cervical cancer may be affected by various additional risk factors, e.g. early initiation of sexual life, multiple sexual partners, smoking or coexistence of other sexually transmitted diseases [12-14].

Chlamydia trachomatis infection and gonorrhea are among the most common bacterial sexually transmitted diseases. According to WHO estimates, there are approximately 127 and 87 million new cases of these diseases each year, respectively [15]. These infections are characterized by similar risk factors as HPV infections, such as young age and a large number of sexual partners. $80-90 \%$ of all C. trachomatis infections in women are asymptomatic and therefore often unrecognized and untreated, leading to chronic infection and further spread in the population [16]. In the literature, there are not many studies on the coexist- gennym, związane między innymi z rozwojem raka szyjki macicy, a także typy o niskim ryzyku, które powodują łagodne przerostowe zmiany w obrębie błon śluzowych i skóry [2]. Szacuje się, że ok. 60 typów HPV z grupy $\alpha$ wywołuje zakażenia nabłonka szyjki macicy, a 30 z nich wiąże się z patogenezą raka szyjki macicy. Najczęściej wykrywanym wirusem wysokiego ryzyka jest HPV 16, który odpowiada za 50-60\% przypadków raka szyjki macicy. HPV 18 jest z kolei przyczyną ok. 10\% nowotworów tego rodzaju [4].

Do zakażeń typami genitalnymi HPV dochodzi głównie przez kontakty seksualne, rzadziej inną drogą, taką jak przenoszenie wirusa $\mathrm{z}$ matki na dziecko podczas ciąży lub porodu albo podczas opieki nad dzieckiem. Większość aktywnych seksualnie kobiet ulega zakażeniu wirusem HPV co najmniej raz w życiu [5]. Zakażenia te zwykle są bezobjawowe i eliminowane przez komórki układu odpornościowego w ciągu 6-18 miesięcy [6]. Tylko u niewielkiego odsetka kobiet zakażenie HPV utrzymuje się, a w przypadku wirusów wysokiego ryzyka może się przyczyniać do rozwoju śródnabłonkowej neoplazji szyjki macicy (cervical intraepithelial neoplasia - CIN) dużego stopnia, która z kolei może ulegać progresji do raka szyjki macicy $[5,7,8]$. Największą podatnością na zakażenie HPV wysokiego ryzyka charakteryzuje się obszar nabłonka szyjki macicy w obrębie tzw. strefy transformacji, gdzie nabłonek wielowarstwowy płaski styka się z nabłonkiem walcowatym [9]. Według dostępnych szacunków co roku zakażeniu HPV ulega ok. 290 milionów ludzi na świecie. W 2018 roku zakażenia HPV spowodowały 570000 nowych przypadków raka szyjki macicy i 311000 zgonów z powodu tego nowotworu [10]. Według Światowej Organizacji Zdrowia (World Health Organization - WHO) 85\% tych zgonów dotyczy krajów rozwijających się. Zakażenia HPV stanowią jednak problem globalny. Dane amerykańskich Centrów Kontroli i Prewencji Chorób (Centers for Disease Control and Prevention - CDC) wskazują, że w Stanach Zjednoczonych co roku zakażeniu HPV ulega ok. 14 milionów osób, u 12000 kobiet występuje rak szyjki macicy, a 4000 umiera z tego powodu. Polska jest jednym z krajów o najwyższych wskaźnikach zachorowalności (ponad 3000 przypadków rocznie) i śmiertelności (7,9 na 100000 kobiet) $\mathrm{z}$ powodu raka szyjki macicy $\mathrm{w}$ Europie [11].

Uważa się, że przetrwałemu zakażeniu HPV oraz rozwojowi raka szyjki macicy mogą sprzyjać dodatkowe czynniki ryzyka, takie jak wczesne rozpoczęcie życia płciowego, liczni partnerzy seksualni, palenie tytoniu lub współistnienie innych chorób przenoszonych drogą płciową [12-14].

Do najczęstszych bakteryjnych chorób przenoszonych drogą płciową należą zakażenie Chlamydia trachomatis oraz rzeżączka. Według szacunków WHO co roku stwierdza się odpowiednio ok. 127 i 87 mi- 
ence of HPV infection in patients with other sexually transmitted infections and diseases. Several epidemiological studies suggest that the problem may affect up to $3.4-6.4 \%$ of women in the entire population [17-20]. Among sexually transmitted diseases, chlamydia, gonorrhea and HIV infections are reported to be the most common concurrent infections with HPV infection [21].

\section{OBJECTIVE}

The main aim of the study was to assess the prevalence of HPV and the risk of HPV infection with other concurrent sexually transmitted infections.

\section{MATERIAL AND METHODS}

Four types of HPV DNA were analyzed (2 types of low oncological risk - HPV 6 and 11, and 2 high oncological risk types - HPV 16 and 18) in infected and uninfected patients with Neisseria gonorrhoeae or C. trachomatis, Treponema pallidum and HIV. The consent of the bioethics committee for research was obtained (KB/236/2012).

We examined 85 sexually active women between 17 and 48 years of age - who reported to the Department of Dermatology and Venereology of the Medical University of Warsaw in 2013-2017.

The study group consisted of 40 women with an average age of $27.4 \pm 6.86$, who had at least one diagnosed sexually transmitted infection (gonorrhea, chlamydia, syphilis). Forty-five women in a similar age group were included in the control group - an average of $29.5 \pm 6.70$ years, who were never treated for sexually transmitted diseases, but underwent preventive examinations for these diseases - the main reason for the test was a relationship with a new partner. From all patients, after signing informed consent forms, swabs from the cervical canal were collected for the diagnostics of $N$. gonorrhoeae, C. trachomatis and HPV 6, 11, 16 and 18 infections, as well as $10 \mathrm{ml}$ of blood to obtain serum for syphilis and HIV infection diagnostics.

For the diagnosis of gonorrhea, methylene bluestained and Gram-stained microscope preparations were used as well as culture on chocolate agar with PolyViteX VCAT 3 (bioMérieux, France) incubated for 24 to 48 hours at $37^{\circ} \mathrm{C}$ in a $5 \% \mathrm{CO}_{2}$ atmosphere, and for chlamydial infection diagnostics direct immunofluorescence (DIF, MikroTrak ${ }^{\circledR}$ Chlamydia trachomatis Direct Specimen Test from Trinity Biotech, USA). In parallel, both infections were diagnosed using real-time PCR. The Bact Extra Pure Kit from EuroClone $^{\circledR}$ (Italy) was used for DNA isolation of $N$. gonorrhoeae and C. trachomatis from material col- lionów nowych przypadków tych chorób [15]. Schorzenia te charakteryzują się podobnymi czynnikami ryzyka jak zakażenia HPV, takimi jak młody wiek i duża liczba partnerów seksualnych. Aż 80-90\% wszystkich zakażeń C. trachomatis u kobiet przebiega bezobjawowo. Oznacza to, że choroba jest często nierozpoznana i nieleczona, co prowadzi do przewlekłego zakażenia i dalszego rozprzestrzeniania się $\mathrm{w}$ populacji [16]. W piśmiennictwie nie ma wielu prac dotyczących współistnienia zakażenia HPV u pacjentów z innymi zakażeniami i chorobami przenoszonymi drogą płciową. Wyniki kilku badań epidemiologicznych wskazują, że problem ten może dotyczyć do 3,4-6,4\% populacji kobiet [17-20]. Spośród chorób przenoszonych drogą płciową do najczęstszych zakażeń współistniejących z zakażeniem HPV należą: chlamydioza, rzeżączka i zakażenie wirusem HIV [21].

\section{CEL PRACY}

Głównym celem pracy była ocena częstości występowania HPV oraz ryzyka współistnienia zakażenia HPV i innych zakażeń przenoszonych drogą płciową.

\section{MATERIAŁ I METODY}

Analizie poddano DNA 4 typów HPV (2 typów niskiego ryzyka onkologicznego - HPV 6 i 11 oraz 2 typów wysokiego ryzyka onkologicznego - HPV 16 i 18) u pacjentek niezakażonych oraz zakażonych Neisseria gonorrhoeae lub C. trachomatis, Treponema pallidum i HIV. Uzyskano zgodę komisji bioetycznej na badania (KB/236/2012).

Badaniem objęto 85 aktywnych seksualnie kobiet w wieku 17-48 lat, które zgłosiły się do Kliniki Dermatologii i Wenerologii Warszawskiego Uniwersytetu Medycznego w latach 2013-2017.

Grupę badaną stanowiło 40 kobiet w wieku średnio $27,4 \pm 6,86$ roku, u których rozpoznano co najmniej jedno zakażenie przenoszone drogą płciową (rzeżączka, chlamydia, kiła). Do grupy kontrolnej włączono 45 kobiet o zbliżonej średniej wieku (29,5 $\pm 6,70$ roku), które nie były wcześniej leczone $\mathrm{z}$ powodu chorób przenoszonych drogą płciową, jednak zostały poddane profilaktycznym badaniom w kierunku tych chorób. Główną przyczyną badań był związek z nowym partnerem. Po podpisaniu przez pacjentki formularzy świadomej zgody pobrano od nich wymazy z kanału szyjki macicy w celu diagnostyki zakażeń $N$. gonorrhoeae, C. trachomatis oraz zakażeń HPV 6, 11, 16 i 18, a także $10 \mathrm{ml}$ krwi w celu uzyskania surowicy do diagnostyki kiły i zakażenia HIV.

Do diagnostyki rzeżączki wykorzystano preparaty mikroskopowe barwione błękitem metylenowym i metodą Grama oraz hodowlę na agarze czekola- 
lected from patients. The DUPLIC $\alpha$ Real Time Neisseria gonorrhoeae $2^{\text {nd }}$ Generation Detection Kit (Euro Clone $^{\circledR}$, Italy) was used to amplify N. gonorrhoeae DNA, and the DUPLIC $\alpha$ Real Time Advanced Dual Easy Chlamydia trachomatis Kit (Euro Clone ${ }^{\circledR}$, Italy) was used to detect C. trachomatis DNA. The DNAsorb-A reagent kit from Sacace Biotechnologies (Sacace Biotechnologies, Italy) was used to isolate HPV genetic material. Amplification of genetic material was carried out with HPV 6/11 and HPV 16/18 Real-TM kits (Sacace Biotechnologies, Italy). All DNA amplifications were performed using a SmartCycler Dx thermocycler ${ }^{\circledR}$ (Cepheid, USA). Serological tests were used for the diagnostics of syphilis and HIV infections. In the case of syphilis, it was a BIOMED VDRL screening test (Poland), whose positive results were verified by the FTA-ABS test. Diagnostics of HIV infection was carried out using the Murex HIV Ag/ Ab Combination HIV screening test (DiaSorin, Italy). None of the tested samples was HIV-positive; therefore no confirmation test was necessary.

\section{Statistical analysis}

Statistical analysis was carried out using Statistica 12 (StatSoft, Poland). The test significance level was set at 0.05 .

\section{RESULTS}

Chlamydiosis was the most common sexually transmitted infection in the study group. A positive direct immunofluorence result concerned 18 women, and real-time PCR 24 women. This discrepancy may result from the higher sensitivity of real-time PCR. Women with C. trachomatis infection detected only in the real-time PCR test were asymptomatic partners of men treated for chlamydia. HPV infection was found in $60 \%$ of the study group and $42.22 \%$ of women in the control group. In the group of women with sexually transmitted diseases, more HPV 16 infections were detected than in the control group: $83.3 \%$ and $63.2 \%$ of all HPV infections, respectively. The result was statistically significant. HPV 16 infection in the study group concerned $58.3 \%$ of women infected with C. trachomatis, $57.9 \%$ of women with gonorrhea, $16.7 \%$ with syphilis and $26.7 \%$ of women in the control group. Infection with HPV 6 or 11 was found in $25 \%$ of those infected with C. trachomatis, $42.1 \%$ with gonorrhea, $50 \%$ with syphilis and $28.9 \%$ of women in the control group. There was a statistically significant relationship between the incidence of $C$. trachomatis infection and HPV 16 infection, but not HPV 6 and HPV 11. There was a statistically significant relationship between gonorrhea and HPV infection and gonorrhea and infection with two different HPV types, dowym z PolyViteX VCAT 3 (bioMérieux, Francja) inkubowanym przez 24-48 godzin w temperaturze $37^{\circ} \mathrm{C} \mathrm{w}$ atmosferze $5 \% \mathrm{CO}_{2}$. W diagnostyce zakażeń chlamydialnych wykorzystano metodę immunofluorescencji bezpośredniej (DIF, MikroTrak ${ }^{\circledR}$ Chlamydia trachomatis Direct Specimen Test firmy TrinityBiotech, USA). Jednocześnie przeprowadzono diagnostykę obu zakażeń metodą real-time PCR. DNA $N$. gonorrhoeae i C. trachomatis izolowano z materiału pobranego od pacjentek przy zastosowaniu zestawu Bact Extra Pure Kit marki EuroClone ${ }^{\circledR}$ (Włochy). Do amplifikacji DNA N. gonorrhoeae wykorzystano zestaw DUPLIC $\alpha$ Real Time Neisseria gonorrhoeae $2^{\text {nd }}$ Generation Detection Kit (Euro Clone ${ }^{\circledR}$, Włochy), a do detekcji DNA C. trachomatis zestaw DUPLIC $\alpha$ Real Time Advanced Dual Easy Chlamydia trachomatis Kit (Euro Clone ${ }^{\circledR}$, Włochy). Do izolacji materiału genetycznego HPV użyto zestawu odczynników DNA-sorb-A firmy Sacace Biotechnologies (Sacace Biotechnologies, Włochy). Amplifikację materiału genetycznego przeprowadzono za pomocą zestawów HPV 6/11 i HPV 16/18 Real-TM (Sacace Biotechnologies, Włochy). Wszystkie amplifikacje DNA wykonano przy użyciu termocyklera SmartCycler ${ }^{\circledR} \mathrm{Dx}$ (Cepheid, USA). W diagnostyce kiły i zakażeń HIV posłużono się testami serologicznymi. W przypadku kiły był to test przesiewowy VDRL firmy BIOMED (Polska). Wyniki dodatnie weryfikowano za pomocą testu FTA-ABS. Diagnostykę w kierunku zakażenia HIV przeprowadzono, wykorzystując test przesiewowy Murex HIV Ag/ Ab Combination HIV (DiaSorin, Włochy). Dla żadnej z próbek badanych nie uzyskano wyniku dodatniego, dlatego nie było potrzeby wykonywania dodatkowej weryfikacji.

\section{Analiza statystyczna}

Analizę statystyczną przeprowadzono za pomocą pakietu Statistica 12 (StatSoft, Polska). Poziom istotności testu ustalono na 0,05 .

\section{WYNIKI}

Najczęstszym zakażeniem przenoszonym drogą płciową w grupie badanej była chlamydioza. Przy zastosowaniu metody immunofluorescencji bezpośredniej oraz real-time PCR wynik dodatni stwierdzono odpowiednio u 18 i 24 kobiet. Rozbieżność ta może być skutkiem wyższej czułości techniki real-time PCR. Kobiety z zakażeniem C. trachomatis wykrytym wyłącznie w badaniu real-time PCR były bezobjawowymi partnerkami mężczyzn leczonych z powodu chlamydii. Zakażenie HPV stwierdzono u $60 \%$ pacjentek z grupy badanej i 42,22\% z grupy kontrolnej. U pacjentek z chorobami przenoszonymi drogą płciową wykryto więcej zakażeń HPV 16 niż w grupie kon- 
and HPV 16 was always one of the types. The percentage of women infected with two types of HPV in the study group was $22.5 \%$ and was higher than in the control group (13.3\%), but the result was not statistically significant. No relationship was found between HPV infections and syphilis. HPV 18 was not detected in any of the patients. The results are shown in tables $1-5$.

\section{DISCUSSION}

The impact of sexually transmitted diseases on HPV infection and progression of high- and lowgrade squamous intraepithelial lesion may be associated with various mechanisms. One of them is the induction of inflammation, leading to the formation of oxidative metabolites and reduction of cell-mediated immunity. Free radicals damage DNA and proteins that inhibit apoptosis, which leads to genomic instability. The secretion of cytokines, such as IL-1 and IL-8 and chemokines, contributes to the maintenance of inflammation in C. trachomatis-infected patients. The consequent damage to the cervical epithelium may facilitate the penetration and indirectly HPV replication and promote chronic infection and progression of lesions to CIN II/III and cervical cancer. Hypertrophy and metaplasia of the cervix frequently occurring in this situation may also contribute to the persistence of HPV infection [22-25]. The correlation trolnej. Stanowiły one odpowiednio 83,3\% i 63,2\% wszystkich zakażeń HPV. Różnica była istotna statystycznie. W grupie badanej zakażenie HPV 16 występowało u 58,3\% kobiet zakażonych C. trachomatis, u 57,9\% kobiet z rzeżączką i u 16,7\% z kiłą. W grupie kontrolnej infekcję HPV 16 stwierdzono u 26,7\% kobiet. Zakażenie HPV 6 lub $11 \mathrm{w}$ grupie badanej stwierdzono u 25\% kobiet zakażonych C. trachomatis, u 42,1\% kobiet z rzeżączką i u $50 \%$ z kiłą. W grupie kontrolnej zakażenie HPV 6 lub 11 występowało u 28,9\% kobiet. Stwierdzono statystycznie istotną zależność między występowaniem zakażeń C. trachomatis i HPV 16, natomiast nie wykazano takiego związku dla HPV 6 i 11. Wykazano ponadto istotną statystycznie zależność pomiędzy rozpoznaniem rzeżączki a zakażeniem HPV oraz rozpoznaniem rzeżączki a zakażeniem dwoma różnymi typami HPV - przy czym zawsze jednym z typów był HPV 16. Odsetek kobiet zakażonych dwoma typami HPV w grupie badanej wyniósł 22,5\% i był wyższy niż w grupie kontrolnej (13,3\%), jednak różnica nie była istotna statystycznie. Nie stwierdzono zależności między zakażeniami HPV a kiłą. U żadnej z pacjentek nie wykryto HPV 18. Wyniki przedstawiono w tabelach 1-5.

\section{OMÓWIENIE}

Wpływ chorób przenoszonych drogą płciową na zakażenie HPV i progresję zmian śródnabłonkowych

Table I. Occurrence of sexually transmitted infections in the study group (division based on diagnostic methods)

Tabela I. Występowanie zakażeń przenoszonych drogą płciową w grupie badanej (podział na podstawie zastosowanych metod diagnostycznych)

\begin{tabular}{|c|c|}
\hline Pathogen (diagnostic methods)/Typ drobnoustroju (metody diagnostyczne) & $\begin{array}{l}\text { Number of women with a }(+) \text { result/ } \\
\text { Liczba kobiet } z \text { wynikiem dodatnim }(+)\end{array}$ \\
\hline N. gonorrhoeae (culture)/N. gonorrhoeae (hodowla) & $19(47.5 \%)$ \\
\hline N. gonorrhoeae (real-time PCR)/N. gonorrhoeae (real-time PCR) & $19(47.5 \%)$ \\
\hline C. trachomatis (DIF)/C. trachomatis (DIF) & $18(45 \%)$ \\
\hline C. trachomatis (real-time PCR)/C. trachomatis (real-time PCR) & $24(60 \%)$ \\
\hline T. pallidum (serological tests VDRL, FTA)/T. pallidum (testy serologiczne VDRL, FTA) & $6(15 \%)$ \\
\hline HIV (EIA IV-generation)/HIV (EIA IV generacja) & 0 \\
\hline
\end{tabular}

Table 2. Occurrence of HPV I 6 infections in subjects infected and not infected with C. trachomatis

Tabela 2. Występowanie zakażeń HPV 16 u pacjentek niezakażonych i zakażonych C. trachomatis

\begin{tabular}{lccc} 
C. trachomatis infection/ & & HPV I6 infection/Zakażenie HPV I6 \\
Zakażenie C. trachomatis & Yes/Tak & No/Nie & Sum/Suma \\
\cline { 2 - 4 } Yes/Tak & 14 & 43 & 61 \\
\hline No/Nie & 18 & 53 & 85 \\
\hline Sum/Suma & 32 & & 63 \\
\hline
\end{tabular}

V-square test $=6.02, p=0.0141, \chi^{2}>\chi_{\alpha}{ }^{2}$ the variables are correlated. $\Phi^{2}=0.07172, O R=3.34,95 \%$ Cl: 1.24-9.05.

Test $V$ kwadrat $=6,02, p=0,0141, \chi^{2}>\chi_{\alpha}^{2}$ zmienne sq zależne. $\Phi^{2}=0,07172, O R=3,34,95 \% \mathrm{Cl}:$ I,24-9,05. 
Table 3. Occurrence of HPV 6 and II infections in subjects infected and not infected with $C$. trachomatis

Tabela 3. Występowanie zakażeń HPV 6 i I I u pacjentek niezakażonych i zakażonych C. trachomatis

\begin{tabular}{lccc} 
C. trachomatis infection/ & \multicolumn{3}{l}{ HPV 6 and I I infection/Zakażenie HPV 6 i I I } \\
\cline { 2 - 4 } Zakażenie C. trachomatis & Yes/Tak & No/Nie & Sum/Suma \\
Yes/Tak & 6 & 18 & 24 \\
\hline No/Nie & 20 & 41 & 61 \\
\hline Sum/Suma & 26 & 59 & 85 \\
\hline
\end{tabular}

V-square test $=0.49, p=0.4857, \chi^{2}<\chi_{\alpha}^{2}$ the variables are correlated.

Test V kwadrat $=0,49, p=0,4857, \chi^{2}<\chi_{\alpha}^{2}$ zmienne sq zależne.

Table 4. Occurrence of HPV 16 infections in subjects infected and not infected with N. gonorrhoeae

Tabela 4. Występowanie zakażeń HPV 16 u pacjentek niezakażonych i zakażonych N. gonorrhoeae

\begin{tabular}{lccc} 
N. gonorrhoeae infection/ & \multicolumn{3}{c}{ HPV I6 infection/Zakażenie HPV I6 } \\
\cline { 2 - 4 } Zakażenie N. gonorrhoeae & Yes/Tak & No/Nie & Sum/Suma \\
Yes/Tak & 11 & 8 & 19 \\
\hline No/Nie & 21 & 45 & 66 \\
\hline Sum/Suma & 32 & 53 & 85 \\
\hline
\end{tabular}

-square test $=4.22, p=0.0399, \chi^{2}>\chi^{2}$ the variables are correlated. $\Phi^{2}=0.07 \mid 72, O R=2.95,95 \% \mathrm{Cl}: 1.02-8.53$

Test $V$ kwadrat $=4,22, p=0,0399, \chi^{2}>\chi_{\alpha}^{2}$ zmienne sq zależne. $\Phi^{2}=0,07$ I 72, OR $=2,95,95 \%$ Cl: I,02-8,53.

Table 5. Occurrence of simultaneous infection with two types of HPV in subjects infected and not infected with N. gonorrhoeae

Tabela 5. Występowanie współzakażeń dwoma typami HPV u pacjentek niezakażonych i zakażonych N. gonorrhoeae

\begin{tabular}{lccc} 
N. gonorrhoeae infection/ & \multicolumn{3}{c}{ Infection with two types of HPV/Zakażenie dwoma typami HPV } \\
\cline { 2 - 4 } Zakażenie N. gonorrhoeae & Yes/Tak & No/Nie & Sum/Suma \\
\cline { 2 - 4 } Yes/Tak & 7 & 12 & 66 \\
\hline No/Nie & 8 & 70 & 85 \\
\hline Sum/Suma & 15 & 70 & 66 \\
\hline
\end{tabular}

$\chi^{2}$ test corrected by Yates correction $=4.62, p=0.0316 . \chi^{2}>\chi_{\alpha}{ }^{2}$ the variables are correlated. $\Phi^{2}=0.07299,0 R=4.23,95 \% \mathrm{Cl}: 1.26-14.14$.

Test $\chi^{2} z$ poprawkq Yatesa $=4,62, p=0,0316 . \chi^{2}>\chi_{\alpha}{ }^{2}$ zmienne sq zależne. $\Phi^{2}=0,07299, \mathrm{OR}=4,23,95 \% \mathrm{Cl}: 1,26-14,14$.

between infection with $C$. trachomatis and cervical cancer was noted as early as in the 1970s. Most of the subsequently published studies also concerned the role of $C$. trachomatis infections as a factor conducive to the persistence of HPV and carcinogenesis [24-26]. However, very similar mechanisms may occur in other causes of cervicitis, e.g. gonorrhea. The existence of similar risk factors of HPV infection and other sexually transmitted diseases makes it difficult to determine whether these diseases are markers of exposure to HPV infection or act as a direct co-factor, increasing the susceptibility to HPV infection [27, 28].

The research conducted in the study shows that in women with positive results for C. trachomatis infection, there is 3.34-fold higher risk of HPV 16 detection than in the control group. Verhoeven et al. presented similar results on the relationship between $C$. trachomatis and high-risk HPV infections. In addition, the latter authors found a relationship dużego i małego stopnia może mieć związek z różnymi mechanizmami. Jednym z nich jest indukcja stanu zapalnego, która prowadzi do powstawania metabolitów oksydacyjnych i upośledzenia odporności komórkowej. Wolne rodniki uszkadzają DNA i białka hamujące apoptozę, co powoduje niestabilność genomu. Także wydzielanie cytokin, takich jak IL-1 i IL-8, oraz chemokin wpływa na podtrzymywanie stanu zapalnego u pacjentów zakażonych C. trachomatis. Powstające $\mathrm{w}$ ten sposób uszkodzenie nabłonka szyjki macicy może ułatwiać wnikanie i pośrednio replikację HPV oraz sprzyjać przetrwałemu zakażeniu, progresji zmian do stopnia CIN II/III i rozwojowi raka szyjki macicy. Przerost i metaplazja szyjki macicy, które często towarzyszą tej sytuacji, także mogą się przyczyniać do podtrzymywania zakażenia HPV [22-25]. Zależność między zakażeniem C. trachomatis a rakiem szyjki macicy zauważono już w latach 70. XX wieku. W większości późniejszych 
between $C$. trachomatis infection and an increased risk of infection with all types of HPV tested [29]. The Portuguese study also showed a higher risk of infection with all HPV types, but the authors did not detect a statistically significant relationship between C. trachomatis occurrence and high-risk HPV infection. [13]. The rate of C. trachomatis and high-risk HPV co-infection was $16.47 \%$ and was higher than in some European (10\%) [30,31] and American (11\%) studies [32, 33]. However, a study on 129 Lebanese women showed a very high frequency of positive HPV DNA results in patients infected with C. trachomatis (59\%) [34].

Studying concurrent HPV and N. gonorrhoeae infections showed a relationship between these two pathogens (almost 3-fold higher risk of HPV infection than in uninfected persons). There are few publications describing the occurrence of co-infection with gonorrhea and HPV. The Brazilian study showed that this co-infection increased 17.3-fold the relative risk of high-grade cervical intraepithelial neoplasia [35]. There are also studies that show no association between gonorrhea infection and high oncologic risk HPV $[18,36]$.

There was no statistically significant relationship between syphilis and HPV infection, perhaps due to the small number of patients with syphilis or the fact that this disease usually does not cause cervicitis.

In the conducted study, no HPV 18 infection was detected in any of the patients, possibly due to the small size of the study group.

The study found that $17.65 \%$ of infected women were infected with more than one type of HPV. Schmitt et al. obtained similar data, as they showed that $16.5 \%$ of HPV infections were concurrent infections with several types of the virus. The same studies also found that infection with several high-risk HPV types increases the risk of high-grade intraepithelial lesions in the cervix [37].

\section{CONCLUSIONS}

The present study showed an increased risk of HPV infection, and HPV 16 in particular, in women infected with C. trachomatis and N. gonorrhoeae, which suggested the possible impact of C. trachomatis and $N$. gonorrhoeae infections on the persistence of HPV infections and possibly even the concurrent effect of these pathogens as cocarcinogens in the development and progression of cervical lesions. Such results indicate that it may be particularly important to perform cytological tests and, if necessary, other tests diagnosing cervical lesions caused by HPV in women infected with C. trachomatis and N. gonorrhoeae. On the other hand, early diagnostics and treatment of chlamydial infection and gonorrhea can badań również analizowano rolę zakażeń C. trachomatis jako czynnika sprzyjającego przetrwałemu zakażeniu i procesowi kancerogenezy [24-26]. Bardzo podobne mechanizmy mogą dotyczyć także innych przyczyn zapalenia szyjki macicy, np. rzeżączki. Występowanie podobnych czynników ryzyka w zakażeniach HPV i innych chorobach przenoszonych drogą płciową utrudnia ustalenie, czy choroby te są markerami narażenia na zakażenie HPV, czy też stanowią bezpośredni czynnik towarzyszący, który zwiększa podatność na zakażenie HPV [27, 28].

Przeprowadzone badanie wskazuje, że u pacjentek z potwierdzonym zakażeniem $C$. trachomatis ryzyko infekcji HPV 16 jest 3,34-krotnie wyższe w porównaniu z grupą kontrolną. Podobne wyniki dotyczące zależności między C. trachomatis a zakażeniami HPV wysokiego ryzyka przedstawili Verhoeven i wsp. Zaobserwowali oni związek między zakażeniem C. trachomatis a zwiększonym ryzykiem zakażenia wszystkimi badanymi typami HPV [29]. Także w badaniu portugalskim wykazano wzrost ryzyka zakażenia wszystkimi typami HPV, jednak autorzy nie stwierdzili statystycznie istotnej zależności między występowaniem C. trachomatis a zakażeniem HPV wysokiego ryzyka [13]. Częstość występowania zakażenia C. trachomatis i współistniejącego zakażenia HPV wysokiego ryzyka wyniosła $16,47 \%$ i była wyższa niż w niektórych badaniach europejskich (10\%) $[30,31]$ oraz amerykańskich $(11 \%)[32,33]$. W badaniu libańskim przeprowadzonym u 129 kobiet stwierdzono z kolei bardzo wysoką częstość występowania dodatnich wyników testów DNA HPV u pacjentek zakażonych C. trachomatis (59\%) [34].

Badanie współzakażeń HPV i N. gonorrhoeae potwierdziło związek między występowaniem tych dwóch patogenów (prawie 3-krotnie wyższe ryzyko zakażenia HPV niż w przypadku osób niezakażonych). Dostępnych jest niewiele publikacji opisujących występowanie współzakażeń dwoinką rzeżączki i wirusem HPV. W badaniu brazylijskim stwierdzono, że takie współzakażenie wiązało się z 17,3-krotnym wzrostem względnego ryzyka śródnabłonkowej neoplazji szyjki macicy dużego stopnia [35]. Dostępne są również badania, które nie wykazują żadnego związku między rzeżączką a HPV wysokiego ryzyka onkologicznego $[18,36]$.

Nie stwierdzono statystycznie istotnej zależności między kiłą a zakażeniem HPV - być może ze względu na niewielką liczbę chorych na kiłę lub fakt, że choroba ta zazwyczaj nie wywołuje zapalenia szyjki macicy.

$\mathrm{W}$ przeprowadzonym badaniu $\mathrm{u}$ żadnej z pacjentek nie wykazano zakażenia typem HPV 18, prawdopodobnie $\mathrm{z}$ powodu niewielkiej liczebności grupy badanej.

U 17,65\% zakażonych kobiet występowało zakażenie więcej niż jednym typem HPV. Podobne dane 
probably contribute to the reduction of chronic highrisk HPV infections.

\section{CONFLICT OF INTEREST}

The authors declare no conflict of interest. przedstawili Schmitt i wsp., stwierdzając, że zakażenia współistniejące kilkoma typami wirusa stanowią 16,5\% zakażeń HPV. W tych samych badaniach wykazano, że zakażenie kilkoma typami HPV wysokiego ryzyka zwiększa proawdopodobieństwo wystąpienia śródnabłonkowych zmian dużego stopnia w obrębie szyjki macicy [37].

\section{WNIOSKI}

W przeprowadzonym badaniu wykazano zwiększone ryzyko zakażenia HPV, zwłaszcza typem HPV 16, u kobiet zakażonych C. trachomatis i N. gonorrhoeae. Może to wskazywać na potencjalny wpływ zakażeń C. trachomatis i N. gonorrhoeae na przetrwałość zakażeń HPV, a być może nawet jednoczesny wpływ tych drobnoustrojów jako kokancerogenów na powstawanie i progresję zmian w obrębie szyjki macicy. Wyniki te pokazują, że wykonywanie badań cytologicznych, a w uzasadnionych przypadkach także innych badań diagnostycznych w kierunku zmian szyjki macicy wywoływanych przez HPV jest szczególnie uzasadnione u kobiet zakażonych C. trachomatis i N. gonorrhoeae. Wczesna diagnostyka i leczenie zakażeń chlamydialnych oraz rzeżączki może się prawdopodobnie przyczynić do ograniczenia przetrwałych zakażeń HPV wysokiego ryzyka.

\section{KONFLIKT INTERESÓW}

Autorzy nie zgłaszją konfliktu interesów.

\section{References}

\section{Piśmiennictwo}

1. Latsuzbaia A., Arbyn M., Dutta S., Fischer M., Gheit T., Tapp J., et al.: Complete genome sequence of a novel human gammapapillomavirus isolated from a cervical swab in Luxembourg. Genome Announc 2018, 6, e000114-e000118.

2. Doorbar J., Quint W., Banks L., Bravo I.G., Stoler M., Broker T.R., et al.: The biology and life-cycle of human papillomaviruses. Vaccine 2012, 30, 55-70.

3. Bernard H.U., Burk R.D., Chen Z., van Doorslaer K., zur Hausen H., de Villiers E.M.: Classification of papillomaviruses (PVs) based on 189 PV types and proposal of taxonomic amendments. Virology 2010, 401, 70-79.

4. Doorbar J.: Molecular biology of human papillomavirus infection and cervical cancer. Clin Sci 2006, 110, 525-541.

5. Tota J.E., Chevarie-Davis M., Richardson L.A., deVries M., Franco E.L.: Epidemiology and burden of HPV infection and related diseases: implications for prevention strategies. Prev Med 2011, 53, 12-21.

6. Ghittoni R., Accardi R., Chiocca S., Tommasino M.: The role of human papillomaviruses in carcinogenesis. Ecancermedicalscience 2015, 29, 526.

7. Kjaer S.K., Frederiksen K., Munk C., Iftner T.: Long-term absolute risk of cervical intraepithelial neoplasia grade 3 or worse following human papillomavirus infection: role of persistence. J Natl Cancer Inst 2010, 102, 1478-1488.

8. Monsonego J., Cox J.T., Behrens C., Sandri M., Franco E.L., Yap P.S., et al.: Prevalence of high-risk human papilloma virus genotypes and associated risk of cervical precancerous lesions in a large U.S. screening population: data from the ATHENA trial. Gynecol Oncol 2015, 137, 47-54.

9. Doorbar J.: Model systems of human papillomavirus-associated disease: Papillomavirus disease models. J Pathol 2016, 238, 166-179.

10. Ferlay J., Colombet M., Soerjomataram I., Mathers C., Parkin D.M., Piñeros M., et al.: Estimating the global cancer incidence and mortality in 2018: GLOBOCAN sources and methods. Int J Cancer 2019, 144, 1941-1953.

11. Pikala M., Burzyńska M., Maniecka-Bryła I.: Years of life lost due to cervical cancer in Poland in 2000 to 2015. Int J Env Res Public Health 2019, 16, E1545.

12. Matos A., Moutinho J., Pinto D., Medeiros R.: The influence of smoking and other cofactors on the time to onset to cervical cancer in a southern European population. Eur J Cancer Prev 2005, 14, 485-491. 
13. Silva J., Cerqueira F., Ribeiro J., Sousa H., Osório T., Medeiros R.: Is Chlamydia trachomatis related to human papillomavirus infection in young women of southern European population? A self-sampling study. Arch Gynecol Obstet 2013, 288, 627-633.

14. Pista A., de Oliveira C.F., Cunha M.J., Paixao M.T., Real O.: Risk factors for human papillomavirus infection among women in Portugal: the CLEOPATRE Portugal Study. Int J Gynecol Obstet 2012, 118, 112-116.

15. Newman L., Rowley J., Vander Hoorn S., Wijesooriya N.S., Unemo M., Low N., et al.: Global Estimates of the prevalence and incidence of four curable sexually transmitted infections in 2012 based on systematic review and global reporting. PLoS One 2015, 10, e0143304.

16. Shaw K., Coleman D., O'Sullivan M., Stephens N.: Public health policies and management strategies for genital Chlamydia trachomatis infection. Risk Manag Healthc Policy 2011, 4, 57-65.

17. Bellaminutti S., Seraceni S., De Seta F., Gheit T., Tommasino M., Comar M.: HPV and Chlamydia trachomatis co-detection in young asymptomatic women from high incidence area for cervical cancer. J Med Virol 2014, 86, 1920-1925.

18. Verteramo R., Pierangeli A., Mancini E., Calzolari E., Bucci M., Osborn J., et al.: Human Papillomaviruses and genital co infections in gynaecological outpatients. BMC Infect Dis 2009, 9, 16.

19. Mendoza L., Mongelos P., Paez M., Castro A., Rodriguez-Riveros I., Gimenez G., et al.: Human papillomavirus and other genital infections in indigenous women from Paraguay: a cross-sectional analytical study. BMC Infect Dis $2013,13,531$.

20. Zhang D., Li T., Chen L., Zhang X., Zhao G., Liu Z.: Epidemiological investigation of the relationship between common lower genital tract infections and high-risk human papillomavirus infections among women in Beijing, China. Grce M. PLoS One 2017, 12, e0178033.

21. Liu J., Liu W., Liu Y., Zhou X., Zhang Z., Sun Z.: Prevalence of microorganisms co-infections in human papillomaviruses infected women in Northern China. Arch Gynecol Obstet 2016, 293, 595-602.

22. Braaten K.P., Laufer M.R.: Human papillomavirus (HPV), HPV-related disease, and the HPV vaccine. Rev Obstet Gynecol 2008, 1, 2-10.

23. Schachter J., Hill E.C., King E.B., Coleman V.R., Jones P., Meyer K.F.: Chlamydial infection in women with cervical dysplasia. Am J Obstet Gynecol 1975, 123, 753-757.

24. Finan R.R., Tamim H., Almawi W.Y.: Identification of Chlamydia trachomatis DNA in human papillomavirus (HPV) positive women with normal and abnormal cytology. Arch Gynecol Obstet 2002, 266, 168-171.

25. Paavonen J.: Chlamydia trachomatis infections of the female genital tract: state of the art. Ann Med 2012, 44, 18-28.

26. Woodman C.B., Collins S., Winter H., Bailey A., Ellis J., Prior P., et al.: Natural history of cervical human papillomavirus infection in young women: a longitudinal cohort study. Lancet 2001, 357, 1831-1836.

27. Trottier H., Franco E.L.: The epidemiology of genital human papillomavirus infection. Vaccine 2006, $24,4-15$.

28. Burchell A.N., Winer R.L., de Sanjosé S., Franco E.L.: Chapter 6: Epidemiology and transmission dynamics of genital HPV infection. Vaccine 2006, 24 Suppl 3, 52-61.

29. Verhoeven V., Baay M., Weyler J., Avonts D., Lardon F., Royen P., et al.: Concomitant Chlamydia trachomatis and human papilloma virus infection cannot be attributed solely to sexual behaviour. Eur J Clin Microbiol Infect Dis 2004, 23, 735-737.

30. Lehmann M., Groh A., Rödel J., Nindl I., Straube E.: Detection of Chlamydia trachomatis DNA in cervical samples with regard to infection by human papillomavirus. J Infect 1999, 38, 12-17.

31. Wallin K.L., Wiklund F., Luostarinen T., Ångström T., Anttila T., Bergman F., et al.: A population-based prospective study of Chlamydia trachomatis infection and cervical carcinoma: Chlamydia trachomatis before cervix cancer. Int J Cancer 2002, 101, 371-374.

32. Giuliano A.R., Papenfuss M., Mendez Brown de Galaz E., Feng J., Abrahamsen M., Denman C., et al.: Risk factors for squamous intraepithelial lesions (SIL) of the cervix among women residing at the US-Mexico border. Int J Cancer 2004, 109, 112-118.

33. Molano M., Weiderpass E., Posso H., Morré S.A., Ronderos M., Franceschi S, et al.: Prevalence and determinants of Chlamydia trachomatis infections in women from Bogota, Colombia. Sex Transm Infect 2003, 79, 474-478.

34. Tamim H., Finan R.R., Sharida H.E., Rashid M., Almawi W.Y.: Cervicovaginal coinfections with human papillomavirus and Chlamydia trachomatis. Diagn Microbiol Infect Dis 2002, 43, 277-281.

35. de Abreu A.L., Malaguti N., Souza R.P., Uchimura N.S., Ferreira É.C., Pereira M.W., et al.: Association of human papillomavirus, Neisseria gonorrhoeae and Chlamydia trachomatis co-infections on the risk of high-grade squamous intraepithelial cervical lesion. Am J Cancer Res 2016, 6, 1371-1383.

36. Lazenby G.B., Taylor P.T., Badman B.S., McHaki E., Korte J.E., Soper D.E., et al.: An association between Trichomonas vaginalis and high-risk human papillomavirus in rural Tanzanian women undergoing cervical cancer screening. Clin Ther 2014, 36, 38-45.

37. Schmitt M., Depuydt C., Benoy I., Bogers J., Antoine J., Arbyn M., et al.: Multiple human papillomavirus infections with high viral loads are associated with cervical lesions but do not differentiate grades of cervical abnormalities. J Clin Microbiol 2013, 51, 1458-1464.

Received: 19.08 .2019

Accepted: 15.03 .2020

Otrzymano: $19.08 .2019 \mathrm{r}$

Zaakceptowano: $15.03 .2020 \mathrm{r}$.

How to cite this article

Bukowska E., Młynarczyk-Bonikowska B., Malejczyk M., Przedpełska G., de Walthoffen S.W., Młynarczyk G., Majewski S.: Human papillomavirus (HPV) coinfection with other sexually transmitted infections in patients of the Department of Dermatology and Venereology at the Medical University of Warsaw. Dermatol Rev/Przegl Dermatol 2020, 107, $138-147$. DOI: https://doi.org/10.5114/dr.2020.96355. 